\title{
Juvenile polyposis of infancy in a child with deletion of BMPR1A and PTEN genes: Surgical approach
}

\author{
Patrícia Horta Oliveira ${ }^{a, *}$, Catarina Cunha ${ }^{a}$, Susana Almeida ${ }^{b}$, Ricardo Ferreira ${ }^{b}$, \\ Sofia Maia ${ }^{c}$, Jorge Manuel Saraiva ${ }^{c, d}$, Maria Francelina Lopes ${ }^{a, d}$
}

\author{
${ }^{a}$ Department of Pediatric Surgery, Pediatric Hospital, Centro Hospitalar e Universitário de Coimbra Av. Afonso Romão, \\ Santo António dos Olivais, 3000-602 Coimbra-Portugal \\ ${ }^{\mathrm{b}}$ Pediatric Gastrenterology Unit, Pediatric Hospital, Centro Hospitalar e Universitário de Coimbra Av. Afonso Romão, \\ Santo António dos Olivais, 3000-602 Coimbra-Portugal \\ ${ }^{\mathrm{c}}$ Department of Medical Genetics, Centro Hospitalar e Universitário de Coimbra Av. Afonso Romão, Santo António dos \\ Olivais, 3000-602 Coimbra-Portugal \\ ${ }^{\mathrm{d}}$ Faculty of Medicine, University of Coimbra, Rua larga, 3004-504 Coimbra, Portugal
}

Received 9 July 2012; revised 24 September 2012; accepted 26 September 2012

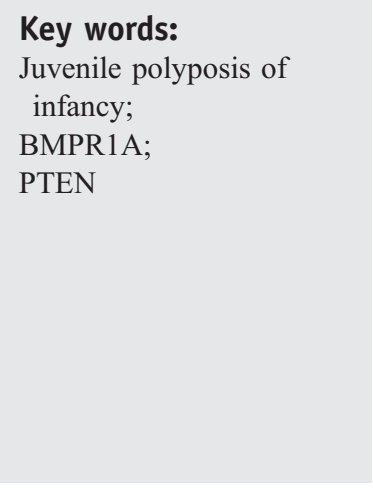

\begin{abstract}
Juvenile polyposis of infancy is the most severe and life-threatening form of juvenile polyposis. This disease typically presents in the first two years of life with gastrointestinal bleeding, diarrhea, inanition, and exudative enteropathy. In very few reports concerning this entity, a large deletion in the long arm of chromosome 10 (10q23), encompassing the PTEN and BMPR1A genes, was found. The authors report a case of delayed diagnosis of juvenile polyposis of infancy at 6 years of age. A $3.34 \mathrm{Mb}$ long de novo deletion was identified at 10q23.1q23.31, encompassing the PTEN and BMPR1A genes. The disease course was severe with diarrhea, abdominal pain, inanition, refractory anemia, rectal bleeding, hypoalbuminemia, and exudative enteropathy. A sub-total colectomy, combined with intraoperative endoscopic removal of ileal and rectal stump polyps, was required for palliative disease control.
\end{abstract}

(C) 2013 Elsevier Inc. All rights reserved.
Juvenile polyposis is a rare condition, defined as the occurrence of multiple juvenile hamartomatous polyps in the gastrointestinal tract $[1,2]$. It includes a clinically and genetically heterogeneous group of conditions and more often presents in older children and young adults [2].

The association of juvenile polyposis and multisystemic involvement is now designated as "PTEN Hamartoma Tumor Syndrome" and encompasses several clinically distinct

* Corresponding author: Tel.: +351 239488700; fax: +351 239717216.

E-mail address: patriciahortaoliveira@gmail.com (P.H. Oliveira). syndromes associated with germline mutations in the tumor suppressor gene PTEN located at chromosome 10q23: Cowden disease, Lhermitte-Duclos disease, Bannayan-RileyRuvalcaba Syndrome and Proteus/Proteus-like Syndrome [2].

In the absence of extra-intestinal features consistent with PTEN Hamartoma Tumor Syndrome, the diagnosis of Juvenile Polyposis Syndrome (JPS) is made when the following criteria are met: more than five juvenile polyps in the colorectum or multiple juvenile polyps throughout the gastrointestinal tract or any number of juvenile polyps in an individual with a family history of juvenile polyposis 
[1,3]. This disease affects 1 in 100,000 to 1 in 160,000 individuals and $20 \%$ to $50 \%$ of cases have a positive family history [3]. The mechanism of inheritance is autosomal dominant and has been associated with mutations in the SMAD4 (18q21.1) or BMPR1A (10q23.2) genes [2,3].

According to clinical presentation and clinical course, JPS is categorized into three different entities: juvenile polyposis coli (colonic involvement only); generalized juvenile polyposis and juvenile polyposis of infancy [3]. Juvenile polyposis coli presents at 5-15 years of age, whereas generalized juvenile polyposis presents at a younger age [3].

Juvenile polyposis of infancy (JPI) constitutes an exceptionally rare disease and very few cases have been reported in the international literature. Unlike other types of juvenile polyposis, JPI manifests early in life, with a severe clinical course and reduced life expectancy $[1,2,4]$. The hallmarks of JPI are early onset of disease (usually within the first 2 years of life), with severe gastrointestinal symptoms, including diarrhea, severe intestinal bleeding, protein-losing enteropathy, intussusception, rectal or polyp prolapse and inanition, leading to death in early childhood [1-3]. JPI is not associated with a family history and has been associated with a de novo germline deletion of a chromosomal region encompassing the PTEN and BMPRIA genes [1,5]. External stigmata (macrocephaly, mental retardation, mucocutaneous lesions, genital pigmentation) may mimic other PTEN Hamartoma Tumor Syndrome, such as Cowden syndrome and Bannayan-Riley-Ruvalcaba syndrome [5]. Facial dysmorphisms, digital clubbing, heart defects and generalized hypotonia are other associated features [2].

\section{Case report}

A 3-year-old male patient with mild mental and motor retardation, macrocephaly (head circumference above the 97th percentile) and minor facial dysmorphisms was referred for genetic consultation. The patient was the second child of a healthy nonconsanguineous couple and had been diagnosed with interatrial communication and patent ductus arteriosus, both corrected in the first year of life. Short stature and digital clubbing were noted but no skin abnormalities were detected at physical examination. Chromosome analysis, subtelomeric and 22q11.2 FISH analysis, molecular testing for Fragile $\mathrm{X}$ syndrome and metabolic studies did not identify any anomalies. The skeletal x-ray films showed only minor alterations: hypoplastic clavicles, eleven pairs of ribs, rectified femoral head and mild posterior plagiocephaly. Magnetic resonance imaging of the brain was normal.

Iron-deficiency anemia was then diagnosed, with hemoglobin level of $9.1 \mathrm{~g} / \mathrm{dL}$, and iron supplementation was started and achieved good initial response.

The child was consulted by a surgeon at the age of 3 years, because of a little umbilical hernia and recurrent "rectal" prolapse. There were previous complaints of multiple loose bowel movements per day and recurrent episodes of bloody stools, which were attributed to the rectal prolapse.

At 5 years of age the patient was diagnosed with bilateral inguinal hernias. At the time of inguinal herniorrhaphy, significant abdominal distension was noticed and three rectal suction biopsies were performed. Immunohistochemical staining of biopsy specimens was not suggestive of Hirschsprung's disease, but did not exclude intestinal neuronal dysplasia.

The rectal prolapse became more frequent at 6 years of age, complicated by rectal bleeding and persistent anemia. The patient's general condition worsened, with progressive abdominal distension and episodes of foul-smelling diarrhea, with mucus and blood, and colicky abdominal pain and tenderness, attributed to enterocolitis that improved after conservative treatment (bowel rest, enemas, bowel decontamination and blood transfusion). During an appendicostomy, performed for colonic decompression and for antegrade enemas, rectal polyps were seen protruding from the anus which were excised. Histopathological examination of the resected specimens revealed juvenile polyps.

Colonoscopy identified further very large polyps throughout the colon, which were highly exudative and hemorrhagic. Magnetic resonance enterography performed for surgical planning revealed additional small bowel polyps, in lesser number and dimensions (Fig. 1).

The patient underwent further genetic testing and arraybased comparative genomic hybridization (Affymetrix $250 \mathrm{~K}$ SNP array) identified two gains (at 6q and 8q) of maternal and paternal origin, respectively, and a de novo deletion at 10q23.1q23.31, $3.34 \mathrm{Mb}$ long, encompassing the PTEN and BMPR1A genes. Genetic counselling of the family was given accordingly to the results.

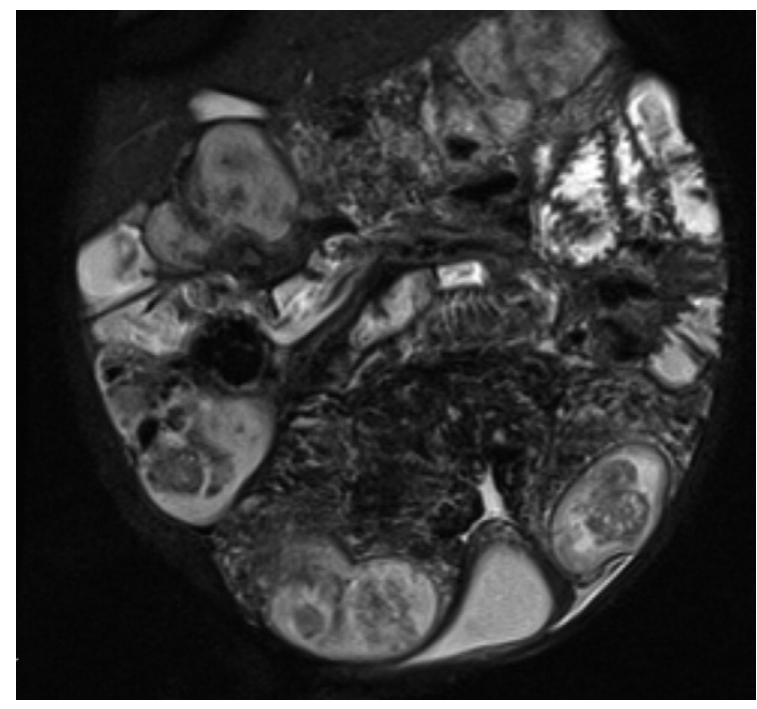

Fig. 1 The magnetic resonance enterography identified large and small bowel polyps. 
Considering the increased risk of developing other types of cancer, a thyroid and testicular ultrasound was performed and did not find any nodule.

At 7 years of age, surgery was proposed because of the severe clinical course with multiple admissions due to refractory anemia and hypoalbuminemia related to blood loss and exudative enteropathy. The presence of widespread intestinal lesions led us to perform subtotal colectomy, with ileosigmoidal anastomosis above the peritoneal reflection and resection of the larger ileal polyps by intraoperative enteroendoscopy and colonoscopic polypectomy in the rectal stump (Figs. 2 and 3). The histological study of the 110 colonic polyps greater than $1 \mathrm{~cm}$ (the biggest ones with 4.5 and $3.5 \mathrm{~cm}$ of height) and of the 21 endoscopicallyresected polyps, revealed juvenile polyposis, without features of dysplasia.

The child had an uneventful recovery and greatly improved his quality of life. There were no more admissions over the 6-month follow-up period and the patient was enrolled in an endoscopic surveillance program.

\section{Discussion}

Hamartomatous Polyposis Syndrome includes a genetically and phenotypically heterogeneous group of conditions [6]. It is very important to identify the individuals at risk for these syndromes and get an accurate diagnosis, for better surveillance and management.

Our patient displayed some clinical signs typical of PTEN Hamartoma Tumor Syndrome (such as macrocephaly), but the clinical presentation was more suggestive of a very rare form of juvenile polyposis syndrome, called Juvenile Polyposis of Infancy (JPI).

Although the diagnosis of polyposis had been established at 6 years of age, this child was diagnosed with "rectal

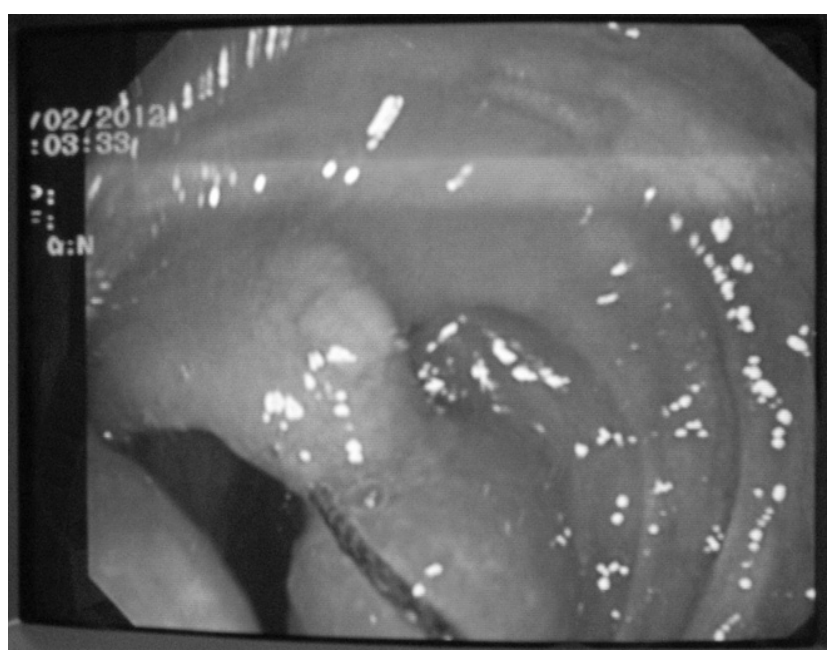

Fig. 2 Resection of the larger ileal polyps by intraoperative enteroendoscopy.

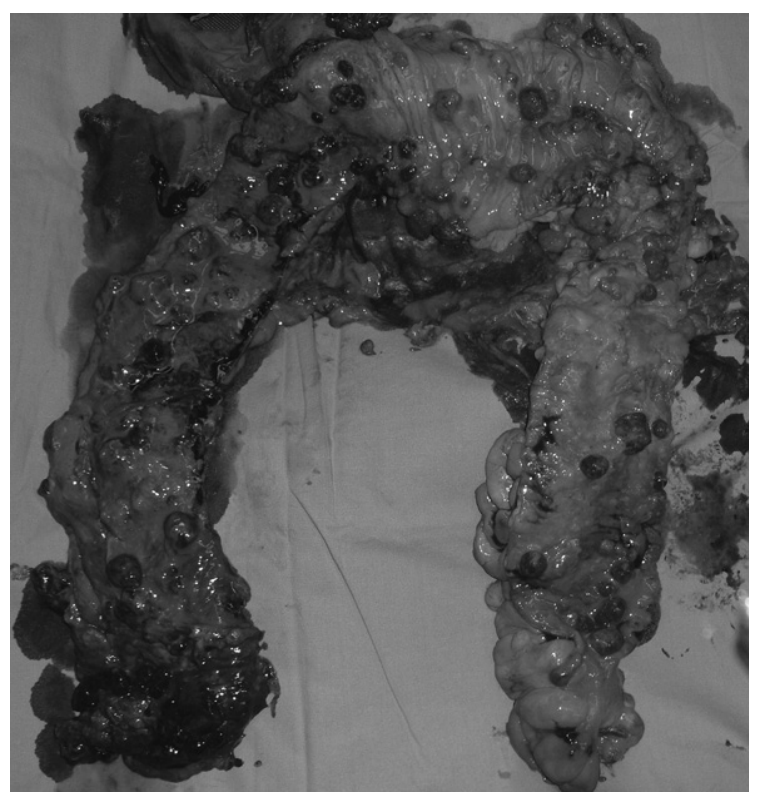

Fig. 3 The resected colon.

prolapse", intermittent rectal bleeding and severe irondeficient anemia when he was 3 years old, which were certainly due to the juvenile polyps uncovered later. A deletion at $10 \mathrm{q} 23$, encompassing the PTEN and BMPR1A genes, was found.

$B M P R 1 A$ and PTEN genes regulate the proliferation of cells of the gastrointestinal tract [1]. BMPR1A gene is located on chromosome 10q23, close to the PTEN gene and the main feature of BMPR1A mutations is digestive polyposis [1]. Delnatte hypothesized that the joint deletion of BMPR1A and PTEN genes is associated with the severe expression of the disease in individuals diagnosed with JPI [1].

However, not all the cases of BMPR1A plus PTEN deletion have a similar clinical picture. A less severe phenotype with childhood-onset and milder clinical course or early onset colorectal cancer in a young adult has been reported $[2,7,8]$. Dahdaleh et al. concluded that, while the range of phenotypes is variable, JPI requires the loss of both BMPRIA and PTEN [5]. Table 1 summarizes the clinical presentation and management in 11 of the previously reported cases with documented deletion of PTEN and BMPR $1 A$ for whom adequate data were available, as well as our patient.

The risk of gastrointestinal malignancy in individuals with juvenile polyposis syndrome is well known, with a lifetime risk of approximately $50 \%$ [5]. That risk seems to be higher in patients with deletion of both BMPR1A and PTEN genes [2]. There is also increased risk of cancer in other locations such as thyroid cancer [2].

Prompt diagnosis and aggressive multidisciplinary medical and surgical treatment are important for the best prognosis and quality of life. Management of JPI should be conservative whenever possible and includes colonoscopy with endoscopic polypectomy instituted early in life, in order 
Table 1 Clinical presentation and management of 12 patients with documented deletion of $P T E N$ and $B M P R 1 A$ genes at $10 \mathrm{q} 23$

\begin{tabular}{|c|c|c|c|c|c|c|c|}
\hline Case & $\begin{array}{l}\text { Reference/Country } \\
\text { (year) }\end{array}$ & Sex & $\begin{array}{l}\text { Age at } \\
\text { diagnosis }\end{array}$ & $\begin{array}{l}\text { Polyps } \\
\text { localization }\end{array}$ & Additional abnormalities & $\begin{array}{l}\text { Surgical treatment } \\
\text { (age) }\end{array}$ & $\begin{array}{l}\text { Evolution (Age at } \\
\text { last follow-up) }\end{array}$ \\
\hline 1 & $\begin{array}{l}\text { Tsuchiya et al./ } \\
\text { USA (1998) [9] }\end{array}$ & M & $2 \mathrm{y}$ & $\begin{array}{l}\text { Duodenum } \\
\rightarrow \text { rectum }\end{array}$ & $\begin{array}{l}\text { Macrocephaly } \\
\text { Cutaneous abnormalities } \\
\text { Minor facial dysmorphisms } \\
\text { Mental retardation }\end{array}$ & No & $(6 \mathrm{y})$ \\
\hline 2 & $\begin{array}{l}\text { Sweet et al./ USA } \\
(2005) \text { [4] }\end{array}$ & $?$ & $18 \mathrm{mo}$ & $\begin{array}{l}\text { Duodenum } \\
\text { and large } \\
\text { bowel }\end{array}$ & $\begin{array}{l}\text { Macrocephaly } \\
\text { Heart defect } \\
\text { Facial dysmorphisms } \\
\text { Digital clubbing } \\
\text { Atresia of portal vein }\end{array}$ & $?$ & $?$ \\
\hline 3 & $\begin{array}{l}\text { Delnatte et al./ } \\
\text { France (2006) [5] }\end{array}$ & $\mathrm{F}$ & $1 \mathrm{mo}$ & $\begin{array}{l}\text { Stomach } \rightarrow \\
\text { rectum }\end{array}$ & $\begin{array}{l}\text { Macrocephaly } \\
\text { Lipomas / hemangiomas } \\
\text { Minor facial dysmorphisms }\end{array}$ & $\begin{array}{l}\text { Colectomy } \\
(10 \mathrm{mo})\end{array}$ & Deceased (3 y) \\
\hline 4 & & $\mathrm{~F}$ & $2.5 \mathrm{mo}$ & $\begin{array}{l}\text { Stomach } \rightarrow \\
\text { rectum }\end{array}$ & $\begin{array}{l}\text { Macrocephaly } \\
\text { Minor facial dysmorphisms }\end{array}$ & $\begin{array}{l}\text { Colectomy } \\
(17 \mathrm{mo})\end{array}$ & Low-grade dysplasia (4 y) \\
\hline 5 & & M & $3 \mathrm{mo}$ & $\begin{array}{l}\text { Stomach } \rightarrow \\
\text { rectum }\end{array}$ & $\begin{array}{l}\text { Macrocephaly } \\
\text { Speckled penis } \\
\text { Hemangiomas } \\
\text { Mental retardation }\end{array}$ & Colectomy (8 y) & Malignization (14 y) \\
\hline 6 & & $\mathrm{~F}$ & $18 \mathrm{mo}$ & $\begin{array}{l}\text { Duodenum, } \\
\text { pancolonic }\end{array}$ & $\begin{array}{l}\text { Macrocephaly } \\
\text { Minor facial dysmorphisms } \\
\text { Heart defect } \\
\text { Atresia of portal vein }\end{array}$ & No & short follow-up (18 mo) \\
\hline 7 & $\begin{array}{l}\text { Salviati et al./Italy } \\
\text { (2006) [7] }\end{array}$ & $\mathrm{F}$ & $6 y$ & Pancolonic & $\begin{array}{l}\text { Heart defect } \\
\text { Cutaneous abnormalities } \\
\text { Minor facial dysmorphisms } \\
\text { Mental retardation }\end{array}$ & No & $\begin{array}{l}\text { Low-grade dysplasia; } \\
\text { prophylactic colectomy } \\
\text { under consideration }(8 \mathrm{y})\end{array}$ \\
\hline 8 & $\begin{array}{l}\text { Menko et al./ } \\
\text { Netherlands (2008) } \\
{[2]}\end{array}$ & M & $3 y$ & $\begin{array}{l}\text { Small and } \\
\text { large bowel }\end{array}$ & $\begin{array}{l}\text { Macrocephaly } \\
\text { Minor facial dysmorphisms } \\
\text { Heart defect } \\
\text { Hypotonia } \\
\text { Mental retardation }\end{array}$ & No & short follow-up (3 y) \\
\hline 9 & & M & $18 \mathrm{mo}$ & $\begin{array}{l}\text { Small and } \\
\text { large bowel }\end{array}$ & $\begin{array}{l}\text { Macrosomia } \\
\text { Hemangioma } \\
\text { Mild facial dysmorphisms } \\
\text { Hypotonia } \\
\text { Mental retardation }\end{array}$ & $\begin{array}{l}\text { Colectomy } \\
(23 \mathrm{mo})\end{array}$ & short follow-up (2 y) \\
\hline 10 & & $\mathrm{~F}$ & $4 y$ & $\begin{array}{l}\text { Stomach } \rightarrow \\
\text { rectum }\end{array}$ & $\begin{array}{l}\text { Macrocephaly } \\
\text { Heart defect } \\
\text { Vesicoureteral reflux } \\
\text { Mental retardation }\end{array}$ & No & $(16 \mathrm{y})$ \\
\hline 11 & & M & $24 \mathrm{y}$ & $?$ & $\begin{array}{l}\text { Macrocephaly } \\
\text { Hypotonia } \\
\text { Mental retardation }\end{array}$ & $\begin{array}{l}\text { Palliative } \\
\text { ileostomy ( } 24 \mathrm{y})\end{array}$ & Deceased $(25 \mathrm{y})$ \\
\hline 12 & $\begin{array}{l}\text { Horta et al./ } \\
\text { Portugal (2012) } \\
\text { [Present report] }\end{array}$ & M & $6 y$ & $\begin{array}{l}\text { Small and } \\
\text { large bowel }\end{array}$ & $\begin{array}{l}\text { Macrocephaly } \\
\text { Heart defect } \\
\text { Digital clubbing } \\
\text { Minor facial dysmorphisms } \\
\text { Hypotonia } \\
\text { Mental retardation }\end{array}$ & $\begin{array}{l}\text { Colectomy } \\
\text { plus } \\
\text { intraoperative } \\
\text { polypectomy }(7 \mathrm{y})\end{array}$ & $(7 \mathrm{y})$ \\
\hline
\end{tabular}

Legends: M, male; F, female; y, years; mo, months.

to reduce the risk for complications, namely malignant transformation. However, JPI is a severe condition with bad prognosis and colectomy is generally required in early childhood for better control of blood loss and hypoalbumine- mia [2]. Five of the 12 cases summarized on Table 1, required early colectomy because of life-threatening complications.

In our case, we found that we had improved both life expectancy and quality of life by using a combined approach 
of subtotal colectomy plus resection of the larger ileal polyps by intraoperative enteroendoscopy and colonoscopic polypectomy in the rectal stump.

\section{References}

[1] Delnatte C, Sanlaville D, Mougenot J-F, et al. Contiguous gene deletion within chromosome arm 10q is associated with juvenile polyposis of infancy, reflecting cooperation between the BMPR1A and PTEN tumor-suppressor genes. Am J Hum Genet 2006;78:1066-74.

[2] Menko FH, Kneepkens CMF, de Leeuw N, et al. Variable phenotypes associated with 10q23 microdeletions involving the PTEN and BMPR1A genes. Clin Genet 2008;74:145-54.

[3] Chow E, Macrae F. Review of juvenile polyposis syndrome. J Gastroenterol Hepatol 2005;20:1634-40.
[4] Sweet K, Willis J, Zhou XP, et al. Molecular classification of patients with unexplained hamartomatous and hyperplastic polyposis. JAMA 2005;294:2465-73

[5] Dahdaleh FS, Carr JC, Calva D, et al. Juvenile polyposis and other intestinal polyposis syndromes with microdeletions of chromosome 10q22-23. Clin Genet 2012;81:110-6.

[6] Gammon A, Jasperson K, Kohlmann W, et al. Hamartomatous polyposis syndromes. Best Pract Res Clin Gastroenterol 2009;23(2): 219-31.

[7] Salviati L, Patricelli M, Guariso G, et al. Deletion of PTEN and BMPR1A on chromosome 10q23 is not always associated with juvenile polyposis of infancy. Am J Hum Genet 2006;79:593-6.

[8] Sanlaville D, Delnatte C, Mougenot J-F, et al. Reply to Salviati et al. Am J Hum Genet 2006;79:596:597.

[9] Tsuchiya KD, Wiesner G, Cassidy SB, et al. Deletion 10q23.2-q23.33 in a patient with gastrointestinal juvenile polyposis and other features of a Cowden-like syndrome. Genes Chromosomes Cancer 1998;21: 113-8. 